\title{
The Verb Form Analysis of Arabic Words Using Depth First Search (DFS) Algorithm
}

\author{
Sulaiman Musthofa Salim*, Ahmad Subhan Yazid ** \\ Informatics Department, Faculty of Science and Technology, UIN Sunan Kalijaga \\ Jl. Marsda Adisucipto No. 155281 Yogyakarta, Indonesia. Tel. + 62-274-540971, Fax. + 62-274-519739 \\ Email: musthofasaliim@gmail.com*, yazid.anfalah@gmail.com**
}

\begin{abstract}
Arabic is one of the international languages and the language of the Qur'an widely used in Islam. Learning basic Arabic is important because the language is the foundation of learning Islam. The fault in determining the verb form will relate to wrong meaning. Overcoming the problem, Shorof is a part of the linguistic arabic used to determine the form and utility of a word. Shorof Praktis Krapyak is one of the shorof books that has been widely used by students in Indonesia because of its reliability and simplicity in recognizing the form of Arabic words. The research was conducted to build a system to determine the Arabic verb forms and their utilities by implementing the Depth First Search (DFS) algorithm. DFS is a blind search algorithm in the artificial intelligent discussion that represents a problem into states, generates them systematically and tests them until a goal state is found. Rules made in recognizing the verb form refer to the Shorof Praktis Krapyak which the system is implemented in an Android application. The test results showed that the system can recognize 100 word samples with $100 \%$ accuracy. In functionality, all of 30 respondents said that test results stated that the system can run properly. The usability test of the system stated that $55.0 \%$ of respondents strongly agreed, $41.6 \%$ are agreed and $3.3 \%$ choose neutral that this system can help them to recognize and analyze the verb forms in Arabic words.
\end{abstract}

Keywords: Arabic, Depth first search, Shorof praktis Krapyak, Verb forms

\section{INTRODUCTION}

Arabic is one of the international languages which is included in the highest number of speakers in the world. Arabic is also often identified with Islam, because the Qur'an and al-Hadith which are the sources of law in Islamic religion are revealed in that language. Therefore, learning Arabic is important, because in addition to being an international communication medium, it can also add insight, especially for Muslims.

Recognizing the structure of verb form is one of the difficulties of understanding Arabic because every structure has different semantic uses. Answering these problems, shorof amd nahwu can be relied upon to recognize and understand the structure of the Arabic word. Shorof is a science that discusses a word before entering in the order of sentences, while Nahwu discusses a word when it is entered in the order of sentences (Dahdah, 1981). The study will focus on shorof because it is the foundation in determining the basic structure of Arabic words. This study refers to a shorof praktis krapyak book that has been widely used in Indonesia.

This study utilizes the Depth First Search (DFS) algorithm to find out which form in the database best matches to the entered word. The results obtained are information about the form of the verb and the utility of the word. The implementation of this study into an Android application will make it easier for people to learn basic Arabic.

\section{MATERIALS AND METHODS}

\section{Shorof and Fiil}

Shorof is a change in the form of words from the first origin namely mashdari (according to the ulama 'Bashroh) and fiil madhi (according to the ulama Kufah) to be another form (sighot) namely fiil mudhori' fiil amr, fiil nahi, fiil nafi, isim fa'il, isim maf'ul, and others. (Kaylani, 2015). In shorof, there are two terms, wazan and mauzun. Wazan is something that becomes a benchmark or must be followed by other sentences. While Mauzun is a word that follows wazan. For example: mauzun أكرم follows the wazan أفعل. In addition, there are several forms (shighot) of words in Arabic, such as fiil (verb), masdar (noun), isim fail (noun of the actor), isim maf'ul (noun of the object), and isim zaman-makan( information of time and place).

Fiil is a word that shows the meaning of himself which is accompanied by one of the 3 time signals: the past, present, future (Kaylani, 2015). Fiil in Arabic is similar to the verb concept in English, each of which is used in a certain period in a different term. Fiil is divided into three types, fiil madhi (past verb), fiil mudhori '(present or future verb), and fiil amr (command verb).

\section{Depth First Search}

Depth First Search (DFS) is one of the Searching algorithms of Artificial Intelligence discussion. Searching presents the problem into a state and systematically generates and tests the states from the initial state until a goal state is found. The search is 
performed on a node in each level from the far left. If a solution has not been found in the deepest level, then the search continues at the right node and the left node can be deleted from memory. If the solution is not found at the deepest level, the search continues at the previous level until a solution is found (Figure 1).

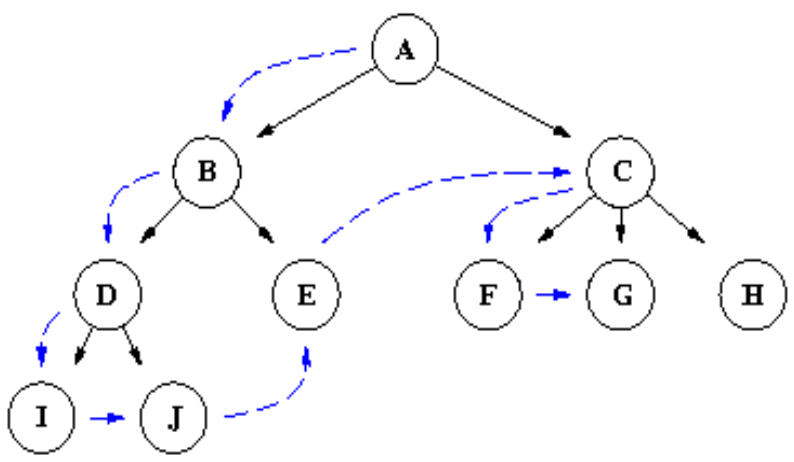

Figure 1. Flow of DFS algorithm.

For the case example in Figure 1, the path traversed to find the destination point 'G' is A-B-D-I-J-E-C-F-G

\section{Procedures}

The method used in this study is the System Development Life Cycle (SDLC). A brief illustration of the SDLC method which consists of several stages is provided in Figure 2

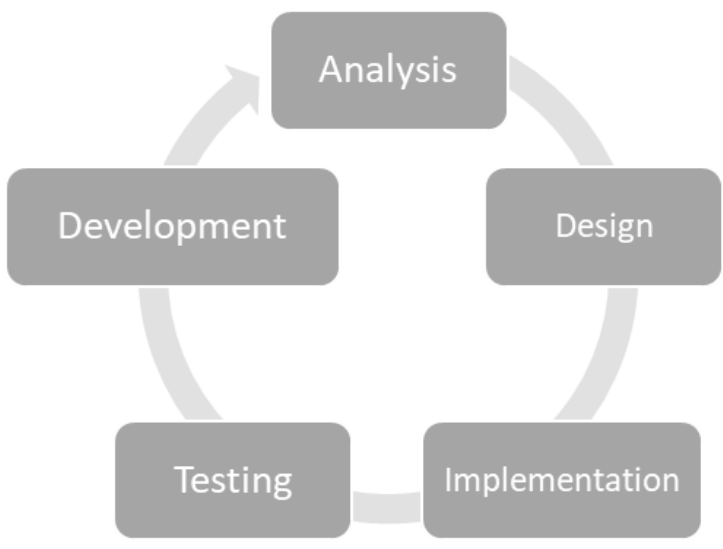

Figure 2. System development life cycle.

The study stages used in this study are:

1. Analysis: at this stage the author will search,collect and analyze what is needed in the system development.

2. Design: the design activities are carried out the flow of the algorithm, interface design, and testing.

3. Implementation: implementation of the system using programming languages.

4. Testing: done by the developer and user, so that is known whether the system is running well or not.

5. Development: follow-up to what will be done to the system.

\section{RESULTS AND DISCUSSION}

The study was implemented using SDLC framework as follows:

Analysis (Replace with Your Sub-Sub-Title of Result) The implementation of this study is an android based application. Therefore, it takes some hardware that supports its development, such as computers with qualified specifications and Android smartphones as testing device. In addition, this study also requires software 'android studio' as a development environment integrated with the SQLite as a data base management system. Given the complexity of the Arabic language, this system is developed only to recognizing the structure of the Arabic word in the form of a fiil madhi.

\section{Design}

Like computer programs in general, the system developed has a flow of inputs, processes, and outputs. The flow of the system is illustrated in the figure 3 .

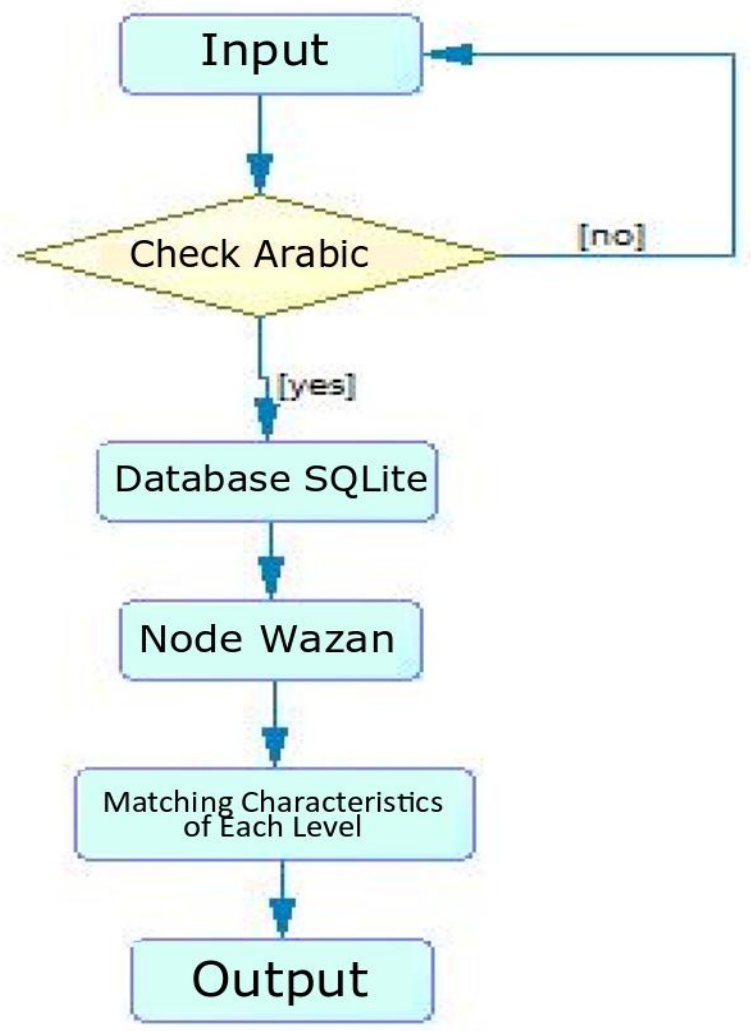

Figure 3. Flowchart of the program design.

Inputs given is in the form of Arabic words processed using the DFS algorithm by referring to the database based on the wazan structure and DFS path as the figure 4. The results of the analysis from the process stage will be displayed. 


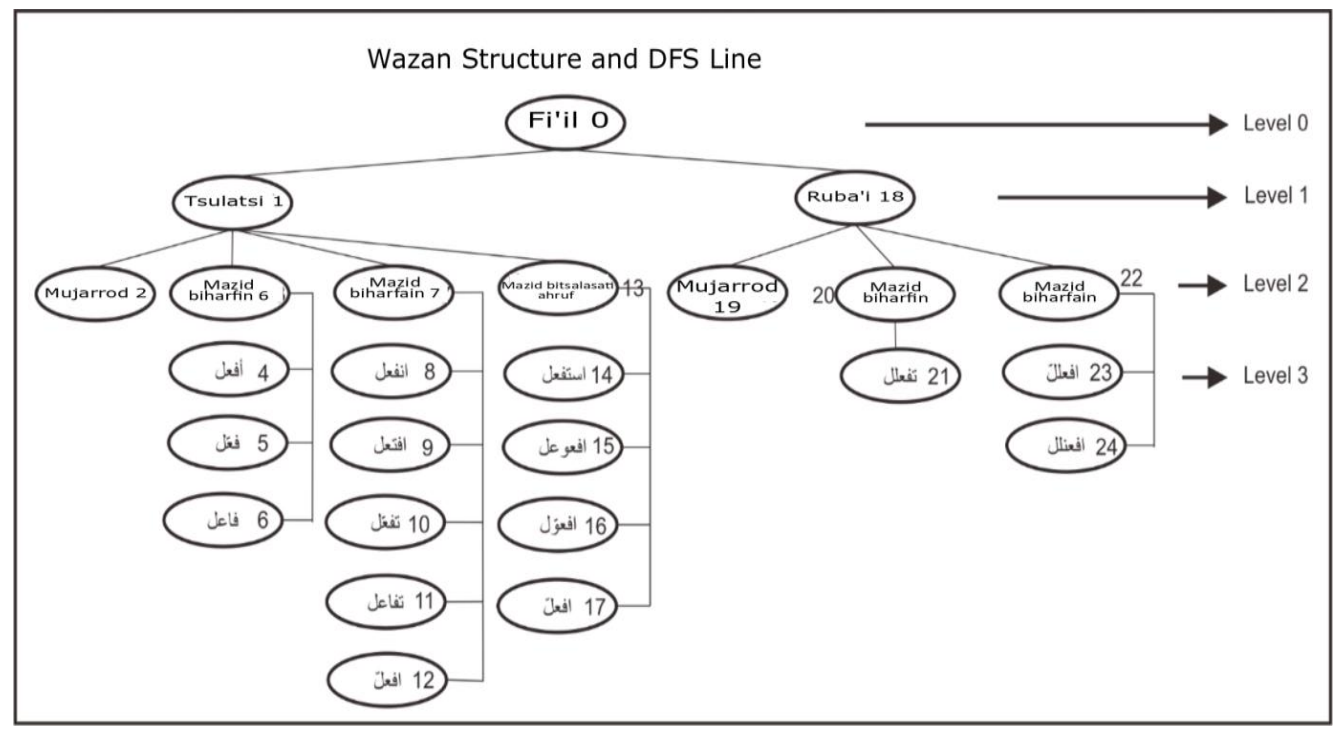

Figure 4. Structure of DFS implementation.

The structure applied has 3 levels, namely: number of letters, number of original and additional letters, and wazan followed. The interface design consists of 3 screens as figure 5 .
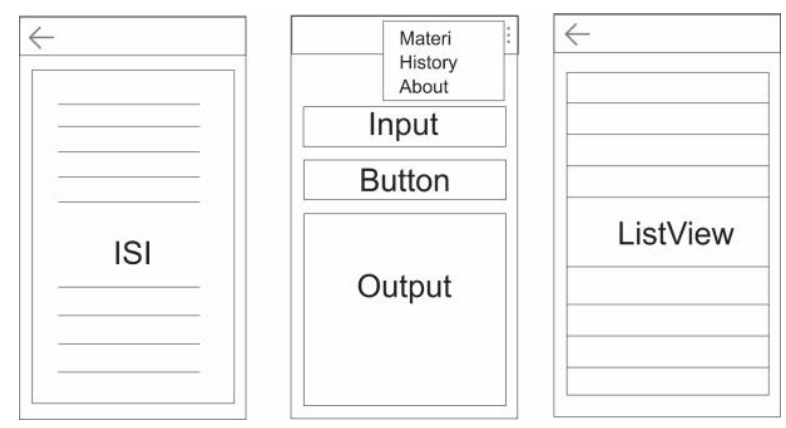

Figure 5. Interface design.

\section{Implementation}

The next step is to implement the results of the analysis and design stage into the system using the programming language. Code writing is done with the Android Studio. This application has complete features, including drag and drop, database integration, and embedded emulators.

Figure 6, displays the user interface. There will be an analysis of the form of each word and rules that match the Arabic words inputed. Here is also the duration of search for each word.

\section{Testing}

System testing is done by the white box and black box method. White box testing was conducted to test 100 words that have various forms of wazan from fiil madli. Of these 100 words, this system is able to provide 97 words of output and 3 words that are not correct (97\%). Based on White box test results, the system can be accepted and in accordance with user needs and this system can work and provide the expected output.

Black Box testing results related to the functionality performed on the system indicate that the system can run well and do the function properly. In the test results, this system obtained a percentage of respondents who stated strongly agree with the number $55.0 \%$, agree with the number $41.6 \%$, neutral with the number $3.3 \%$, disagree and STS strongly disagree with the number $0 \%$. Based on these results it can be concluded that the fiil form analysis system in Arabic based on the Book of Shorof Practical Krapyak is feasible to be used and applied as its function.

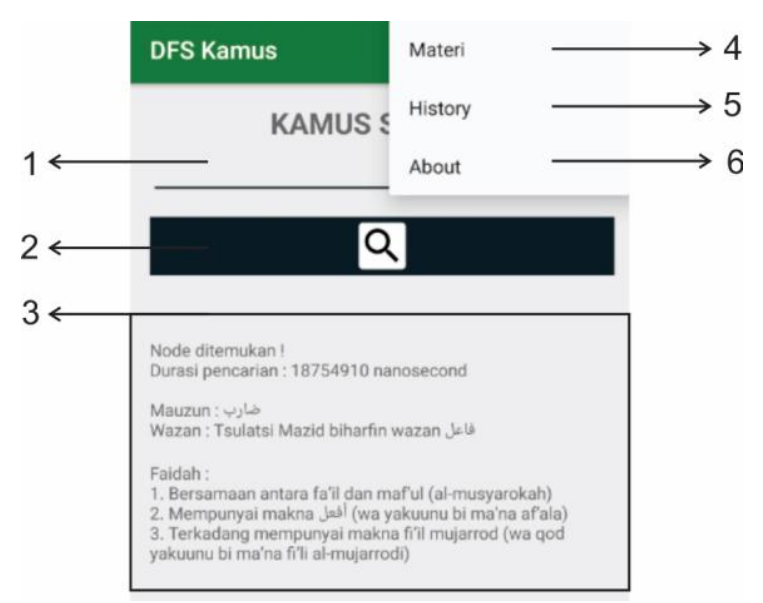

Figure 6. System user interface.

\section{Development}

The test results show that the system has been successfully implemented to analyze the form and utility of verbs (Fiil) in Arabic. To get better results, the system needs to be developed by expanding the scope of the word analyzed so that it can cover the whole 
structure/sighot of the Arabic word. Further development can also be done using different algorithms, so that it can be seen which system is the most efficient to help people understand the basic structure of Arabic words.

\section{CONCLUSIONS}

Android system for verb forms from Arabic has been successfully implemented. the test results also indicate that the system has been running well and in accordance with the objectives. for learning Arabic more complex, it is necessary to develop the system, both from the object of study and testing.

\section{REFERENCES}

Abdillah, N. (2014). Implementasi Algoritma Breadth First Search Pada Analisis Sintaksis I'rob Kalimat Bahasa Arab. Skripsi: Teknik Informatika Fakultas Sains dan Teknologi UIN Sunan Kalijaga Yogyakarta.

Busyro, M. (2012). Shorof Praktis "Metode Krapyak". Yogyakarta: Menara Kudus.

Dahdah, A. (1981). Mu'jam Qowaid al Lughah al Arabiyyah Fi Jadwal Wa Lawahat. Beirut: Maktabah Lubnan.
Farkhan, M. (2013). Sistem Informasi Berbasis Web Untuk Penysusunan dan Penelusuran Silsilah Keluarga Menggunakan Algoritma Depth First Search. Malang.

Kaylani, A. A. (2015). Syarh Al Kaylani. Surabaya: Darul Ilmi.

Kusumadewi, S. (2013). Arficial Intelligence (teknik dan aplikasinya). Yogyakarta: Graha Ilmu.

Ma'shum, S. M. (t.thn.). Al Amtsilah al Tasrifiyah. Surabaya: Maktabah Salim Nabhan.

Muawanah, R. (2018). Analisis Kedudukan I'rob Bahasa Arab Pada Kitab Al-Imrithy Menggunakan Algoritma Breadth First Search (BFS). Yogyakarta.

Schultz, P. D. (2009). Bahasa Arab Baku dan Modern. Yogyakarta: LKiS Yogyakarta.

Sholiq. (2006). Pemodelan Sistem Informasi Berorientasi Obyek dengan UML. Yogyakarta: Graha Ilmu.

Subagyo, F. E. (2013). Implementasi Algoritma Depth First Search (DFS) Pada Rute Bus AKAP AKDP Berbasis Android. Yogyakarta.

Suyanto. (2014). Artificial Intelligence. Bandung: Informatika.

Tanzeh, A. (2011). Metodologi Penelitian Praktis. Yogyakarta: penerbit Teras.

Wardani, K. (2015). Implementasi Algoritma Breadth First Search (BFS) Dalam Arti Kata Bahasa Ilmiah Biologi. Tersedia kuisioner.lp2m.unpkediri.ac.id/mahasiswa/file_artikel/2015/11.1 .03.02.0189.pdf. Diakses pada tanggal 15 Desember 2017.

Wulandari, C. (2015). Implementasi Metode Breadth First Search (BFS) Untuk Text Predictive Pada Kamus Bahasa Indonesia Jepang.simki.unpkediri.ac.id/mahasiswa/file_artikel/2015/11.1.0 3.02.0073.pdf. Diakses pada tanggal 13 Desember 2017.

Zainal A Hasibuan, P. (2007). Metodologi Penelitian Pada Bidang Ilmu Komputer Dan Teknologi Informasi. Depok. 